\title{
Rituals for Social Communication in Folk Theatre of Rajasthan with Special Reference to Performance of Jagdev Kankaali
}

\author{
Yogita Swami
}

Research Scholar, School of Media and Communication at Manipal University, Jaipur. Email:yogitaswami48@gmail.com

\begin{abstract}
:
Rituals have been an important factor in human development of since primitive times, not only as support in the struggle for survival but also for entertainment and education. Rituals have also been used to acknowledge the supremacy of feudal lords, kings, and emperors. Rajasthan, because of its feudalistic character and a very specific geographical condition, have been dependent on the imaginary and superhuman powers of rituals. In the course of time, performers of rituals emerged into groups having expertise in their art and developed specific form and style of performance. This paper explains and analyzes the anthropological interrelation of the rituals, social communication, and folk theatre of Rajasthan through the performance study of the popular folk play Jagdev Kankaali. This study underlines the theoretical aspects of social communication as well as analyzes the performance of the above play along with its ritualistic environment.
\end{abstract}

Keywords: Rituals, social communication, folk theatre, mythology.

\section{Anthropology of Rituals}

The life of the human has always been full of rituals since ages, which cannot be overlooked. Rituals exist in various stages of life, whether it is business, profession, politics or the systems of judiciary. Even the rituals are performed by animals as well. As commonly understood and identified that rituals are related to religion and its practice, they create form of the sacred, communicate doctrine and mold the individual person into the social groups and communities. There are several rituals, which are not religious but secular in their nature, are performed unknowingly but the rituals connected with religion are specific and clear and known to the performer. Throughout the evolution of human being, right since the prehistoric period, millions of million human beings encountered rituals in daily life directly through religion and mythology. The life in the modern times is full of religions and related rituals all over the world.

In fact, use of rituals is quite frequent in every society for managing the hidden and unforeseen conflicts related to human life in respect of sex, power, status and space. Their practice is not limited to these aspects only but extends to find out a way for connecting people to unify and even to their mystical past and the supernatural powers, so as they could be able to create a social unanimity and to form and identifiable community.

(C) AesthetixMS 2020. This Open Access article is published under a Creative Commons Attribution Non-Commercial 4.0 International License (http://creativecommons.org/licenses/by-nc/4.0/), which permits non-commercial re-use, distribution, and reproduction in any medium, provided the original work is properly cited. For citation use the DOI. For commercial re-use, please contact editor@rupkatha.com. 
This is a common belief that ritual provided a ground to originate the performing arts. However, there is hardly any concrete archeological and historical evidence available for asserting such beliefs. Rather, it seems that since primitive period all the performance had the same kind of entertainment qualities as the elements of the ritual had. Arguing further in favour of this theory Richard Schechner emphasizes that:

"Instead of thinking of the binary "ritual or art," one should consider the functions of performance as to what degree does a performance entertain, give pleasure, is made so that it is beautiful, and to what degree is a performance efficacious; made in order to accomplish something like please or appeal to the gods; mark or celebrate an important event or life milestone such as birth, puberty, marriage, or death. Although specific public performances tend to emphasize either entertainment or efficacy, all performances actually are both entertainment and efficacious."

(Schechner 2002: 77)

Turner has looked upon rituals in a different way. He argues that many rituals have a longer life but keep on changing, while several of them remain unchanged maintaining the status quo. According to him the process of practicing ritual itself encourages experiments many a times and discovers new openings.

"The ritual process itself encourages innovation by opening up a space and time for anti-structure. Sometimes rituals change formally through the work of councils, assemblies of ritual specialists, or state authorities. But often, rituals are evolved through changes introduced by individuals at a local level in many cultures and in different situations." (1969:77)².

During the long course of history, a new culture was evolved and new set of gods and goddesses came into existence with a new methodology of worship. Migration has also been a very important factor in the development of the primitive societies. The demographic character became a permanent aspect of the collective life, especially in the areas where nature was not very supportive. Droughts, floods, landslides, and other king of natural calamities forced people to keep moving from one place to another, which emerged as a reason for certain kind of rituals. A large section of human beings migrated to the east, west, and central part of the globe and got mixed up with the local people and further developed another hybrid cultural environment. The music, dances, and art of histrionics also got new colours because of this migrating tendency.

\section{Social Communication with Rituals}

Communication is basically an intrinsically woven composition of various layers of ritual, which often appears to be primitively ritualistic. On the other hand, ritual could be understood as an action, based on symbols. According to James Carey, it is also believed that all the activities with symbols in their character, reproduce culture and ritual, and create the patterns of relation in a particular society, in which, the individual member of that society works as storing house of the practices taking place in the patterns. ${ }^{3}$ (Carry,1947) By means of activity, which are symbolic in nature, a social and cultural world is constructed, and the society starts living in the world, which is build by itself. Consequently, the individual member of the society becomes a representative of his own world, which has been constructed by itself to live in irrespective to any specific gender. This is also a truth that the sequence of the patterns creates the forms, which inherently have double reality, as the reality is not only constructed by the people but also maintained by the 
same people. The ritual represents the primary mechanism, even if the number of mechanism is more than one, through which, sequence of rituals controls and regulates the contrasting, diverse, and casual desires and passions of the human action. Virtually, the rituals are capable of creating and recreating innumerable patterns and forms, beliefs, feelings and moral ideas providing the ground for the firm rooting of the bonds of the society. Hence, the culture is generated by communication, and the community undergoes celebration by means of rituals.

In the modern societies, the complex inter-relation of rituals and communication may comprise several varied activities that include religious practice, sports events, civic festivals, games of cards, wedding ceremonies or the ceremonies related to life and death, etc. that amalgamates perception, assimilation, symbolic synergy, interaction, association and participation in various contexts, which are important and significant, not only for the daily life but for the social life as well. Durkhiem points out that social practice, particularly ritual practice, are responsible for the emergence of the ideas and beliefs. ${ }^{4}$ Filipa Subtil further argues that the presupposition of the communication process generates the beliefs among the individual living in a close knit community:

'The existence of a society presupposes the process of communication and interaction mediated symbolically generating beliefs and representations because individuals living in close mutual proximity to each other through the ritual and the ceremony attain the capacity to create the sacred. This involves a complex and broad ranging understanding of communication as in conflict with reductionist perspectives anchored in scientific and mechanistic conceptions present today in the new domains of information technologies generally conveyed by the engineering and management professional cultures."5 (Philipa Subtil)

However, according to some of the theories, the emphasis has been given through focusing at the international level, co-presence, by means of minor social systems, and dominantly placing at the concrete level, has actually fabricated and manipulated the construction of interpretations out of the applicability associated with rituals as strong social experience with intense communicability at the primary level, which is capable of generating knowledge, emotions and the mustic and occult amalgamation, to some extent. Explaining the sense of communication as culture, James Carry focuses on the construction of meaning.

"In order to explain the construction of meaning, idea centers on ritual and not - and thereby differentiating from other leading figures in cultural studies - in seeking out codes or very general and wide reaching mental structures. Therefore, the culture may be placed at the very centre and identified from the outset as ritual and conversation. This is the sense in which Communication is culture." ${ }^{6}$ (Carey, 1947)

In the present world, the communication is dominated by the modern technologies, and when the presence of rituals are emphasized in the technological environment, the oral and the coexistence moral and descriptive reasons are privileged simultaneously. If we further analyze the situation, the communication is accepted as a symbol for requesting in a ritualistic manner to create an environment of equality, apparently looking like original, since the co-presence and the juxtaposition signify to provide the ground for active feedback as an essential condition for the continuity of the communication. Face to face interaction also contribute for building a strong and deep recognition of others with a feeling of totality and completeness.. Philipa Subtil has explained this relationship with an appropriate example:

".....in conversations we have to deal with the weighing of all the words because this calls into question and puts at risk not only our minds but also our bodies. Talking through a 
conversational process also involves inviting and simultaneously requesting a response, modified through the implicit and explicit expressions of respect, to our objections and differences."7 (Philipa Subtil)

Therefore, it can be summarized that ritual and conflict are closely related to each other. Dispute appear in the mode of ritual exactly same as the conflict acquire the structure of ritual. Process of effective communication is always judged by the conflicting ideas and their resolution. Rituals always play a significant role in the process; not only that they consolidate motivations from political, aesthetic and moral reasoning, but also the ordinary and simple economic interests. Rituals have always provided a profound ground and the strong foundation for creating the order of intimacy, togetherness and communion, and the quest for search of commonly shared and accepted meaning, as well as, deportation and dismissal.

Having a look at the history of medieval India, it is apparent that Islamic rulers in Central Asia regularly attacking the country, but most of them settled here permanently. They further developed a new mixed culture, new language, new music and new philosophical stream of thoughts. The popularity of Sufi practice, Sufi music and Sufi shrines became embedded without religious discrimination. Shrines, popularly called Dargah, of Shekh Nizamuddin at Delhi, Muinuddin Chishti at Ajmer, Salim Chishti at Fatepur Sikri, Haji Ali at Mumbai became the sites of communal harmony. Qawwali (devotional music) concerts were regularly attended by common people of all the religions. Although, the music was forbidden in Islam, but Sufi saints adopted music as means to connect with the almighty. Such concerts were open to all without any discrimination. According to Hazrat Inayat Khan, music was a means of attain ecstasy removing all barricades of religion, caste and creeds. He narrates a story to justify his views:

'In Arabia there is story that when God commanded the soul to enter the body, the soul refused saying that this body seemed to be a prison. Then God asked the angels to sing and dance; and as the soul heard the music it moved to ecstasy, and in that ecstasyit entered the physical body.' (Khan, 1990)

The Sufi saints were wanderers migrating from one place to another along with their followers, influencing the local population with their cultural practice and beliefs. According to the description given by historian G. N. Sharma, Sufi saints left a deep impact on the socio-cultural life of Rajasthan. Although, policies of Islamic ruler of Delhi were not friendly for other religions, but Sufism successfully communicated basic principles of Islam, which influenced the society to a great extent, subsequently, patronized and rewarded by several rulers of Rajasthan.

The influence of Islam began to grow rapidly through missionary effort of mystic groups also which had arrived in India almost simultaneously with the foundation of the Sultanate of Delhi. Of them Shaikh Muin-ud-din Chishti and his eminent disciple Shaikh Hamid-ud-din established their centers at Ajmer and Nagor respectively and made long strides in converting the lower strata in the population by removing the spirit of mistrust and isolation. Their simple and pious life, their intuitive intelligence, and their identifying with the problems of the peoples went a long way in determining the range and sphere of their influence. Their liberal approach towards some of the basic problems of religion and morality not only infused a motive force in the Islamic life in Rajasthan during the 13th century but made it a living ideal for the subsequent ages. ${ }^{9}$

(Sharma, 1968)

The liberal approach of Islam influenced the popular folk theatre of Rajasthan also, which was reflected in their performance through various characters appearing in their texts as antagonists, 
who could resolve the problems of daily life of the people. Sufi devotional music gradually became popular. Considering the increasing influence for creating harmony in the society, the rulers of Rajasthan also extended open patronage as Prof Sharma describes on the basis of several books like Haqeeqat Bahi (1779), Dargah File (1818, Dastari Records (1840) and others as well as the records of Archeological Survey. According to his description:

During the course of these invasions and expansion of missionary activities, Muslim traders, craftsmen and soldiers also settled down in and around Ajmer, Jalor, Nagor, Chitor aad Mandal and openly practiced their religion. The rulers of Rajasthan not only tolerated them but afforded all facilities for their domicile.

In 1707, Araarsingh assigned 100 bighas of land to Qazi Sultan Muhammad and allotted a share of the local tax. Maharana Sangram Singh II in V.S. $1782 \quad(1725 \quad$ A.D. $)$ granted concession to Qazi Abdul Husain at Nand Rai and extended warm hospitality to him. In Jodhpur a Qazi was honoured with the robe of honour on the occasion of Id festival as revealed from the Dastri Records. Similarly, according to the Dasiur Komwdr there were several craftsmen like Ali Nizam, Abdullah, Alaibuksh, and others who were patronised by the State of Jaipur during the 18th century. The Muslim religious activity during the period under review was confined to the construction of tombs and mosques. At Ajmer, Jodhpur; Jaipur, Alwar, Bharatpur, Kotah, Udaipur and their neighbouring areas, mosques were constructed by the Muslims during our period. It appears that on the whole a liberal policy was adopted towards Islam by the rulers of Rajasthan. Both the religions flourished side by side. The rulers were sufficiently tolerant to donate towards the Dargah of Ajmerby way of grant of land or fund. In V.S. 1774 (1717 A.D.) Maharaja Ajit Singh granted the jagir of the village Sarna to the Dargah of Ajmer. Maharana Jagat Singh of Mewar ( 1734-1751 A.D. ) conferred the villages of Rayala, Katdi, Arneta and Kanya on the Dargah of Ajmer. ${ }^{10}$ (Sharma, 1968)

However, the colonial rule never really changed the local lives. Their lives were as miserable as it was before. The socio-economic policies of colonial rulers were meant only to serve the interest of their masters, without any concern for the local population.. The British Raj relocation programs and heavy taxation lead them to rebellion, which was oppressed with a severe blow. Karen Haydock has narrated several stories related to the merciless revenue system of British rulers in his article and the peasant's movement of Indian in his article ' British Dominance and Indian Independence'." The movement resulted into a situation where thousands of lives were sacrificed; Colonial rule ridiculed and marginalized the history, religion, and way of life of the native people and peasants. The land was stolen and resources for the life were snatched in the name of development. The colonial rule virtually denied them access to fundamental rights. On the other hand, all such rules were carried by the local feudal lords and zamindaars further added their own tyranny. The combined attack on the economy changed the character of migration in Rajasthan, which was not with urgency of earning bread and butter for the daily needs only but to save the lives as well, generating a huge crowd of internal migrants.

Society in Rajasthan is no different from the world in respect to the performance of rituals. Rather its characteristics of being a princely state and its geographical location have added further colours. Rituals are performed not only for fostering human life but the environment and nature also has significant place in the themes of the performance of the rituals. Dance, music, plays, imitation games, magical shows, puja (worship) are closely connected with the thread of social knit. 
Musical, dance, oral narratives, and artistic traditions are intertwined with multiple religious scenes throughout Rajasthan and are enacted in public and within family settings. The social and political relationship between artists, artisans, and their patrons are therefore significant aspects of both the histories of these art forums as well as the contemporary artistic environments. Mayaram explores how Neo-Muslim ballads, myths, and other oral performance traditions of this marginal, social and religious groups in Alwar district are evidence of resistance to the dominance of Hindu princely rulers and the pan-Indian discourses of nationalism (1997-2003) ${ }^{12}$ Her research on oral traditions and subaltern identity in Rajasthan draws on the broader traditions of subaltern studies and ethno history, inserting previously ignored marginal groups into narratives of Indian history and political resistance.

\section{Performativity of Rituals in Folk Theatre of Rajasthan}

Folk theatre, a synonym to ritual theatre in its popular term in India, could be divided broadly as secular and religious which is deeply rooted in rituals. Ritual theatre is a collective activity in its character merged due to impact of faith and religion. As an essential character of most of the folk theatres of the country are narrative, i.e. singing and recitation, rooted in mythology and historical contents without any complicated elements and dance movements or gestures. The rich ballad singing traditions like "Pabuji-ki-phad" of Rajasthan and "Nupipaala" of Manipur are also very popular. All these theatrical styles have their own indigenous character, but they are different from each other in terms of staging customs, make up, costumes, and acting style. South Indian traditions of Kathakali and Krishnattam in Kerala emphasize more on dance, but North Indian traditions are focused on singing, like Maach in Madhya Pradesh, Khyal in Rajasthan and Swang in Punjab; while Jatra in West Bengal and Bhavai in Gujarat stress more upon dialogues

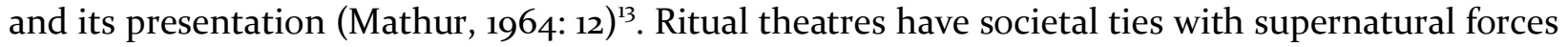
or ancestral spirits which are institutionalized with the procedures of repetitive action, believed to be effective. Prayers are done for seeking the blessings of deities so that the community is protected from death, sickness, natural calamity, etc; and the domestic animals may not die due to disease or epidemic. Prayers are also done for the sufficient rains, good harvest and harmony with the nature as well. There are several rites performed for consoling and pacifying the mourners and to reinstate the communal equilibrium. Gradually, people who tried to associate with the divine, practiced to develop professional expertise to facilitate the relationship. Such people developed the spiritual faculties and imbibed non-corporeal characteristics to help ease the psychological problems and diseases. This practice was possible only through the practice of rituals (Vatsyayan, 1980: 11) ${ }^{14}$.

The community life of the ancient agricultural society generated the group performances incorporating the formal movements, lot of dance and music, offering of vegetables, other eatables articles, feast, fruits, flowers and aromas, organizing the events of taking processions and celebrations, etc. This kind of life routine full of rituals helped to bring sanity and order to the society which was otherwise habitually engaged with the struggle for survival and security.

\section{Jagdev Kankaali: The Blend of Rituals and Mythology}

There is a long series of popular folk and ritualistic theatre in Rajasthan such as Raja Harishchandra, Amar Singh Rathor, Gopichand Bharathari. Jaidev Kankali, etc. However, the 
performance of Jagdev Kankaali is significant among us because of its spectacular performance of interesting rituals. Jagdev Parmar may not be accepted as a historic reality in the genealogy of the Parmar rulers; his legend has an immortal niche in the oral bardic tradition. The folktale Jagdev Parmar ni Katha (the story of Jagdev Parmar) translated in 1868 A.D. and later included in Rajasthani in 1934 A.D. unfold the account and adventures of Jagdev. King Udaideep of Malwa (a region in north central province) had two queens; one from Solanki and other from Vaghela clan. The younger one proves dearer to the king when her son Randhwal is declared heir apparently superseding the elder Solankiji. The younger queen - the green-eyed monster of jealousy coaxes the king to banish Jagdev. The obedient son accepts his father's command quite sincerely and reaches the city of Pattan in Gujarat along with his wife. He seeks employment in the royal court. Jagdev is deputed to guard the Queen's palace that is frequented every night by Bhairav. Jagdev has a duel with Bhairav and injures him. Bhairav laments his defeat in front of his mother Kankali (an incarnation of Lord Goddess Kali). She comes and tests Jagdev's faith and chivalry. His wife is word-bound to cut off her husband's head and offer it to Kankali. Kankali restores the head.

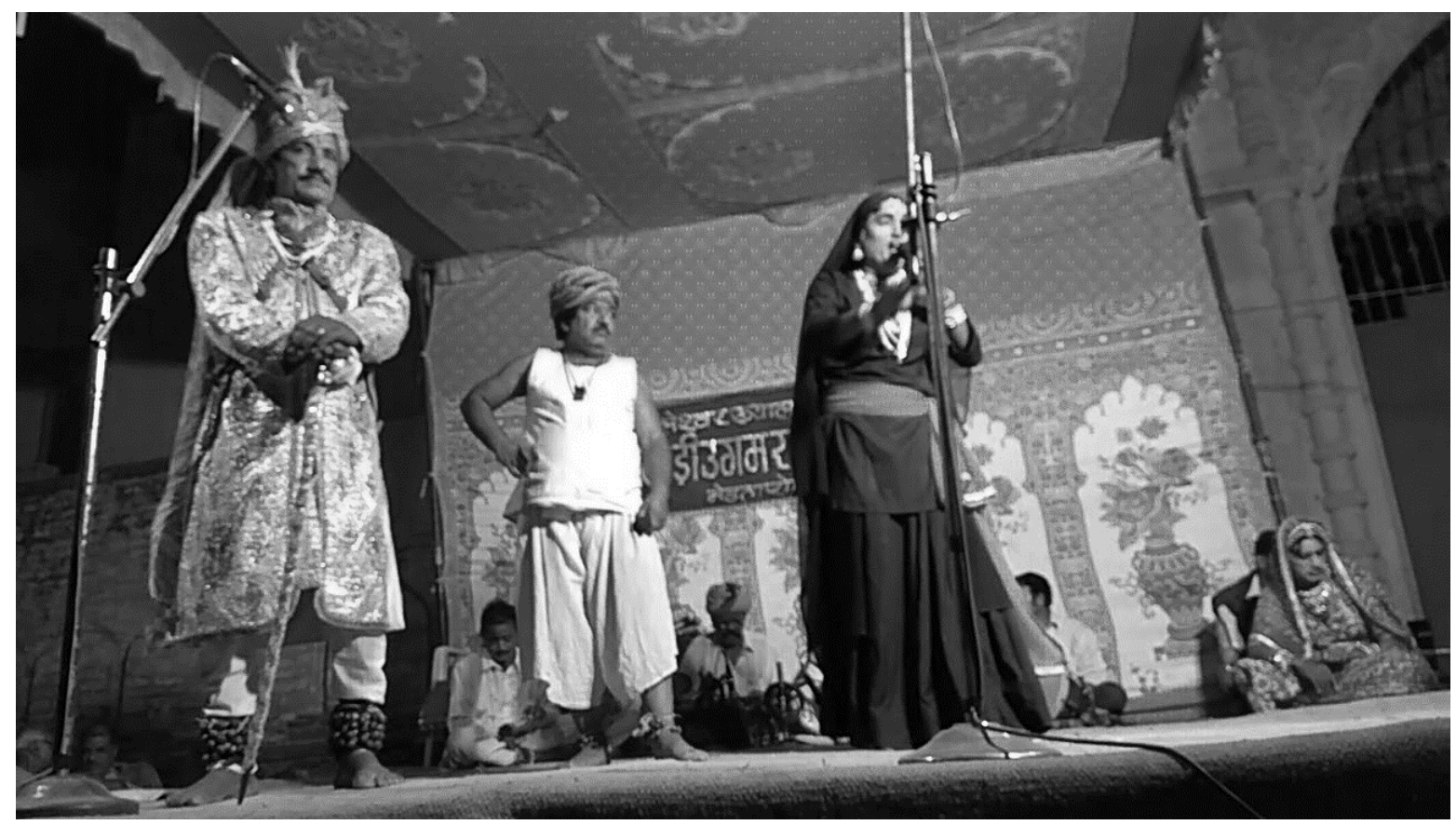

[Picture Source: Archive of Prof. Ravi Chaturvedi]

As a general assumption, that by following the religious systems, one can connects with the supernatural forces. Such forces either are controlled by the god and other Celestica beings or could be mobilized in a desired direction, or else, live in the sorrounding nature, such as mountains, rivers, rocks, trees, caves, etc. Hence it is a common feature that every performance begins with the worship of Goddess Saraswati or Lord Ganesha followed by the ritualistic song and dance. Life in Rajasthan, being a feudal state, is specially known for varied rituals in their full fan and fare style. Festivals of Rajasthan are generally religious in their character but the performances are not essentially religious, which take their content from the daily life and other socio-political events. However, there is lot for the aesthetic pleasure, interpretative content and an organizational setup (Hollander, 2012, 16). ${ }^{15}$ 
Most of the folk and ritualistic theatres are basically street shows in their structure or they are held in the open air on temporarily erected stages and combine both entertainment and education. But unlike street plays, the efforts are not required to draw the audiences in the performances as they are presented at certain special occasions or during the festival season, such as Holi and Diwaali festivals or at some other social events sponsored by the community (Taneja 1980). ${ }^{16}$ Another strong aspect of folk theatre of Rajasthan is that watching the performances is not limited to one social caste. The performance of Jagdev Kankaali creates an occasion where people from all castes assemble to watch the performance. Jagdev Kankaali is basically a Khyal performance which is one of the rare social occasions in rural Rajasthan where different castes mingle with each other with relative ease. Usually, upper and lower caste members do not mingle in public events (Sharma, 2017: 65$)^{17}$. These performances become an occasion to eat, drink, perform, and be happy - in other words, achieve total fulfillment. There are no fixed or marked seats for audience members to sit and watch these performance. Most of them sit on the ground. At times, audience members sit on the stage itself, not only to watch the performances but to participate in the rituals performed in the beginning or in the middle of the performances.

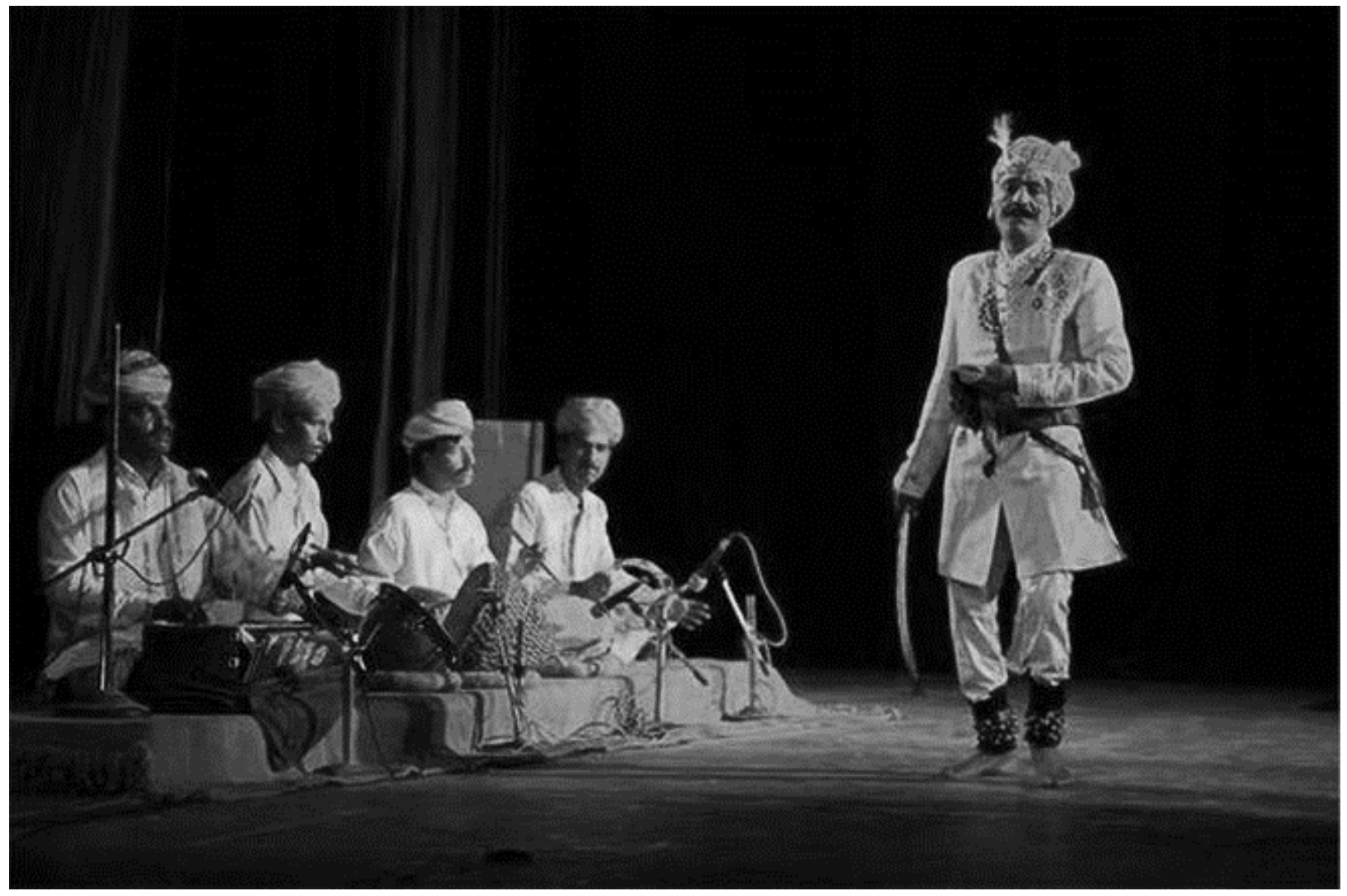

[Picture Source: Archive of Prof. Ravi Chaturvedi]

Unlike other folk theatre forms, the performance of Jagdev Kankaali helps the spectators assign two major functions: one, helping people to understand the world around them; and two, help people to articulate the understanding of their worlds by making a connection with other members of the community and feeling united through a realization of their common conditions. Another quality of the performance is its recitative character. The play is performed quite often on a regular basis throughout the year, even then the audiences watch them with full enthusiasm. Authors talked to 
several members of the audience of these performances but the answer is same that they know the story very well; they know the course of happenings in the performance very well; they very well know the songs and the musical scores, etc. What they enjoy most is the festivity and the opportunity of socialization and to showcase their status as well. As a tradition, the members of the audience generally offer money to the performers during the running performances, if they like some particular actor/s or a particular scene (Mittu, 2004) ${ }^{18}$. However, that is not all, the most important reason to draw the audience in the performance of Jagdev Kankaali is its rituals of sacrifice, showcasing the faith in natural and supernatural characters with a very strong visual pull of the performance. The performance creates a thrill among the spectators when Jagdev cuts his head, followed by an extreme excitement when the head is restored by the goddess Kankaali. The emotionally charged crowd joins the performers in the prayer with full devotion.

\section{Conclusion}

It is unimaginable that the human being can exist in solitude without getting effected by the surroundings conditions and the environment. The important question is that the person should be taken care of like a small plant and finds helping conditions to grow and develop properly. Rituals are the junctures of the human life, where the life takes a turn, and celebration is needed to felicitate every juncture. The arguments reach to the point where it is proved that:

- Rituals cannot be performed without celebrations, since it an essential aspect, which involves every one amongst the relatives and the community as a whole, who gather to bless and to pour the best wishes to the concerned person as Manohar Bharadwaj say:

"The rituals are known to be the great time-tested tools in the traditional system which help carve out a personality" (Bharadwaj, 2008: 27) ${ }^{19}$.

Undoubtedly, rituals have played a great role in the growth and development of the human being since the primitive period when the struggle for survival was the only priority. From rehearsals for the successful hunting to the celebration of success was full of rituals. The result also emrges out of these arguments that:

- Gradually, with the development of a logical system to the everyday problems, related rituals were replaced but the logic alone was not considered to be the trustworthy until supported by the performance of the ritual. This process is seen during the various phases of the development of the human being and the society as well.

The transformation of the social systems also witnessed the changes in rituals since new gods and deities were emerging. In feudal system, the king who became the representative of the god and father of the entire population of the kingdom initiated new rituals suitable to his well being and prosperity.

Rajasthan used to be full of feudal lords who controlled their subjects through various kinds of rituals which were performed during the festivals and especial occasions. During the course of performing these rituals, several groups of performers emerged and acquired the expertise. These groups carried out the skill of performing rituals generation after generation. It is evident from the socio-cultural history of Rajasthan that:

- The ritualistic celebrations and performance started acquiring the particular form and styles according to their geographical and environmental characteristics, and socio-cultural traditions as well. Rammat in Bikaner and Jaisalmer region, Swang in north central 
Rajasthan, Khyal in central-west Rajasthan, Nautanki in east and Gawari in south evolved under these conditions.

However, their content was mostly religious and mythological, but the local heroes who were warriors, saints, etc. were also included in the repertoire of these performances. The love stories also became popular along with the contemporary socio-political issues (Borana 2002: iv) ${ }^{20}$.

To sum up, according to Prof Ravi Chaturvedi,

...this will not be wrong to say that Indian traditions are the resultants of certain historical processes. They actually construct the structure of Indian culture. These traditions belong to several ideologies such as Vedic, Buddhism, Jainism, tribal and later, Islam and western modernity. The process of synthesis has, therefore, constructed these traditions. In this historical process, synthesis had been the dominant organizing principle of the Indian culture, which was a central focus of Indian classical and folk theatre. $^{21}$ (Chaturvedi, 2019)

In the modern times, these forms and styles are used in the contemporary theatre because of their effective communication power and their semiotics. Modern directors, while doing experiments for using the semiotics of rituals, have defined them in the perspective of modern theories of performance. According to them, performance is a process to enter into someone else's body or in other word; this 'someone else' who may be a shaman, a priest, or anyone else takes over the performer's body. This someone else is called a character in the performance, which could be a demon, a saint, a god, etc.

Similarly, a performer in everyday life is not necessarily playing anyone but himself or herself as an ordinary person. His identity is revealed only when he enacts a character. However, the rules outside the stage are several with vast range. There could be absolutely formal performance, such as leader of a particular religion, or a political group, as well as some space for the non formal or semi formal performance of a profession, and some simple improvised performances looking like real, simple interaction. (Stebbins 1977:141) ${ }^{22}$. But in any case, a performer has to pass through some rituals before entering into somebody other's body. ${ }^{23}$ It is believed that the rituals help to a great extent in the process.

\section{Notes:}

'Schechner, Richard, Performance Studies: An Introduction, (London \& New York Routledge, 2002)

${ }^{2}$ Turner, VictorThe Ritual Process: Structure and Anti-Structure,(1969), Aldine Publishing Company, Chicago)

${ }^{3}$ Carry, James W., Communication as Culture, (1947), Thompson, pp.321-2

${ }^{4}$ Durkheim, Émile, Sociology and Philosophy (2009) Routledge

${ }^{5}$ Subtil, Filipa, James W. Carey's cultural approach of communication, http://www.scielo.br/scielo.php?pid (Last access on 14 October 2019)

${ }^{6}$ Carry, James W., Communication as Culture, (1947), Thompson, p.321

${ }^{7}$ Subtil, Filipa, James W. Carey's cultural approach of communication, http://www.scielo.br/scielo.php?pid (Last access on 14 October 2019) 
${ }^{8}$ Khan, Hazrat Inayat. The Sufi Message, (1990), Motilal Banarasi Das, Delhi, p221

${ }^{9}$ Sharma, G. N., Social Life in Mediaval Rajasthan, 1968, Educational Publishers, Agra, pp. 219-223

${ }^{10}$ Archaeological Survey, XXIII, pp. 35-39 quoted bt G. N. Sharma in his book Social Life in Mediaval Rajasthan1968, Educational Publishers, Agra, pp. 219-223

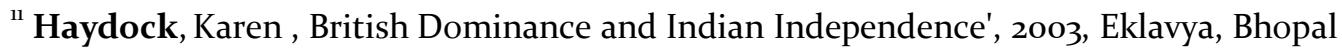

(Access https://www.eklavya.in/pdfs/Books on 18 December 2019)

${ }^{12}$ Mayaram, S, Resisting Regimes: Myth, Memory and Shaping of a Muslim Identity, .(1997, Delhi, Oxford University Press)

${ }^{13}$ Mathur, J.C. Drama in Rural India, .(1964), New York, Asia Publication House,

${ }^{14}$ Vatsyayan, KTraditional Indian Theatre: Multiple Streams,(1980,New Delhi National Book Trust) p.11

${ }^{15}$ Hollander,JIndian folk theatres, .(2012,Routledge, London ) p.16

${ }^{16}$ Taneja, Jaidev (1980), Adhunik Bhartiya Rang Paridrishya, Taxshila Publication, Delhi.

${ }^{17}$ Sharma, D'There is Nothing Like Nautanki' in R. Chaturvedi \& T. Gupta (Eds), Contemporary Indian Theatre (2017, Rawat Books, Jaipur) p.65

${ }^{18}$ To offer money or other articles is a common practice in almost all the folk and ritualistic performances in Rajasthan. These offerings are decided according to the status of the person. This could be anything between 10 to 5000 Rupees, or an offer to bear all the expenses of the performance, or an invitation to the upcoming performance. This occasion is used as an opportunity to showcase the social and the financial status also. Sometimes these performances are used as an opportunity for match making also. If the matchmaking is successful, the parents of both the sides offer, money and food to the performing group, and request the group to pray the deity for the blessing.

${ }^{19}$ Bharadwaj,M, Cultural and Traditional History of India, (2008 New Delhi, Cyber tech Publications) p.27

${ }^{20}$ Borana, R.Rajasthan ki Rammaten, (2002, Jodhpur, Rajasthan Sangit Natak Akadmi), p.iv

${ }^{21}$ Chaturvedi, Ravi, Modernization (Re)Addressed in Indian Theatre, in Modernization of Asian Theatres (Nagata, Yesushi \& Chaturvedi, Ravi (2019) Springer, p.124

${ }^{22}$ Stebbins, GDeisarte System of Expression; (1977,New York Dance Horizons) p.141

${ }^{23}$ The process of entering into some other body is called 'parkaaya pravesh' in Sanskrit theatre

Yogita Swami is a research scholar in the School of Media and Communication at Manipal University, Jaipur. She is perusing her study for the degree of $\mathrm{Ph} \mathrm{D}$. Her study is focused on the portrayal of Soldiers in Bollywood War Movies. She did her certificate course from Film and Television Institute, Pune in Film Appreciation. She has presented papers in International and national seminars and has contributed chapter in the book "Changing Trends of Indian Cinema" by Kanishka Publisher, Delhi (2019). She is member of the IFTR (FIRT) Asian Theatre Working Group. 